\section{Selective medium for the isolation of Bordetella pertussis and parapertussis}

\author{
ENID M. SUTCLIFFE AND J. D. ABBOTT From the \\ Public Health Laboratory, Withington Hospital, \\ Manchester
}

Benzyl penicillin is widely used as a selective agent in media for the isolation of Bordetella pertussis and parapertussis. We report the use of cephalexin (Muggleton, O'Callaghan, Foord, Kirkby, and Ryan, 1968) as a selective agent with a wider spectrum than penicillin.

Preliminary experiments were carried out with a freeze-dried strain of Bord. pertussis originally isolated by Dr E. C. Armstrong on an antibiotic-free medium, and a number of freeze-dried strains of Bord. parapertussis. Surface viable counts were made on Oxoid charcoal agar (CM119) with $10 \%$ horse blood and various concentrations of cephalexin (93\% potency). The strain of Bord. pertussis was not inhibited by 10 to $80 \mu \mathrm{g} / \mathrm{ml}$ of cephalexin, but there was some inhibition at $100 \mu \mathrm{g} / \mathrm{ml}$. The strains of Bord. parapertussis were more sensitive to cephalexin: there was little or no inhibition by $40 \mu \mathrm{g} / \mathrm{ml}$, slight inhibition by $60 \mu \mathrm{g} / \mathrm{ml}$, and greater inhibition by levels of 80 to $100 \mu \mathrm{g} / \mathrm{ml}$. At $60 \mu \mathrm{g} / \mathrm{ml}$ of cephalexin some strains of Bord. parapertussis showed variation of colony size after five days' incubation but this had disappeared after seven days. From these preliminary experiments we chose a level of $40 \mu \mathrm{g} / \mathrm{ml}$ of cephalexin for use as a selective agent in the charcoal-blood-agar base. During these experiments we also found that some strains of Bord. parapertussis showed marked variation of colony size on certain batches of charcoal-bloodagar containing no antibiotic; other strains were unaffected. This inhibitory effect of some batches of charcoal-blood-agar was removed by the addition of a final concentration of $1 \%$ Difco proteose peptone no. 3 .

\section{Comparison of Isolation of Bord. pertussis on Two Media}

MEDIUM A (ROUTINE)

Charcoal agar plates with a final concentration of $10 \%$ horse blood, $1 \%$ Difco proteose peptone no. 3 , and 0.25 únits benzyl penicillin per $\mathrm{ml}$.

Received for publication 27 April 1972.
MEDIUM B (EXPERIMENTAL)

As above with the substitution of $40 \mu \mathrm{g} / \mathrm{ml}$ cephalexin for the benzyl penicillin.

Plates were incubated for seven days at $36^{\circ} \mathrm{C}$ before final reading. Fresh batches were poured each week and stored at $4^{\circ} \mathrm{C}$ before use. Twenty-three routine pernasal swabs were inoculated directly on medium $\mathbf{A}$, then placed in stabs of charcoal agar without blood or antibiotic and later the same day inoculated onto medium B. For the next 23 swabs the procedure was reversed and a further 29 swabs were inoculated onto both media from the charcoal agar stabs. The results of isolation of Bord. pertussis are shown in Table I and the growth of commensals in Table II.

\begin{tabular}{ll}
\hline Medium & $\begin{array}{l}\text { Number of Isolations } \\
\text { of B. pertussis }\end{array}$ \\
\hline & 2 \\
$\begin{array}{l}\text { A only } \\
\text { B only }\end{array}$ & 3 \\
$\begin{array}{l}\text { A \& B } \\
\text { Total number } \\
\text { of swabs }\end{array}$ & 18 \\
\hline
\end{tabular}

Table I Isolation of Bord. pertussis on roltine $(A)$ and experimental $(B)$ media

\begin{tabular}{|c|c|c|c|c|c|}
\hline \multirow[t]{2}{*}{ Medium } & \multicolumn{4}{|c|}{$\begin{array}{l}\text { No. of Swabs According to Growth of } \\
\text { Commensals }\end{array}$} & \multirow[t]{2}{*}{$\begin{array}{l}\text { Total No. } \\
\text { of Swabs }\end{array}$} \\
\hline & $\begin{array}{l}<20 \\
\text { Colonies }\end{array}$ & $\begin{array}{l}20-50 \\
\text { Colonies }\end{array}$ & $\begin{array}{l}>50 \\
\text { Colonies }\end{array}$ & $\begin{array}{l}\text { Overgrown } \\
\text { by Moulds }\end{array}$ & \\
\hline $\begin{array}{l}\mathbf{A} \\
\mathbf{B}\end{array}$ & $\begin{array}{l}38 \\
64\end{array}$ & $\begin{array}{l}5 \\
2\end{array}$ & $\begin{array}{r}31 \\
9\end{array}$ & $\begin{array}{l}1 \\
0\end{array}$ & $\begin{array}{l}75 \\
75\end{array}$ \\
\hline
\end{tabular}

Table II Growth of commensals on routine $(A)$ and experimental $(B)$ media

Although the isolation rate on each medium was similar, the experimental medium gave a significant reduction in growth of commensals, which facilitated the examination of the plates. The inhibition included penicillin-resistant staphylococci, some coliforms, and many, but not all, strains of Haemophilus influenzae. In a previous series of tests the results of direct inoculation of the routine medium was compared with a lower concentration of cephalexin $(30 \mu \mathrm{g} / \mathrm{ml})$ in charcoal-blood-agar inoculated from charcoal agar stabs. Of 146 swabs tested, Bord. pertussis was grown from 25 swabs on both media, from two swabs on the routine penicillin medium only, and from six swabs on the cephalexin medium only.

If serotyping is to be carried out it may be necessary to subculture strains of Bord. pertussis isolated on the cephalexin medium onto penicillin charcoalblood-agar or antibiotic-free charcoal-blood-agar 
as there may be poor development of type-specific antigen on the cephalexin medium (N. W. Preston, personal communication).

\section{Conclusions}

A medium containing Oxoid charcoal agar (CM119) with $10 \%$ horse blood, $1 \%$ Difco proteose peptone no. 3 , and $40 \mu \mathrm{g} / \mathrm{ml}$ of cephalexin has proved satisfactory for the isolation of Bord. pertussis. The isolation rate was as good on this medium as on the routine medium containing penicillin, but plates were easier to read due to the reduction in numbers of commensals. The cephalexin plates should be incubated for seven days at $36^{\circ} \mathrm{C}$ before being reported as negative, since some strains of Bord. parapertussis may show variation in colony size with shorter periods of incubation.

We thank Mr R. W. Boyd of Glaxo Laboratories for the supply of cephalexin; Dr Hans Lautrop, Dr N. W. Preston, and Dr F. W. Sheffield for freeze-dried strains of Bord. parapertussis, and Dr E. C. Armstrong for the strain of Bord. pertussis.

\section{Reference}

Muggleton, P. W., O’Callaghan, Cynthia H., Foord, R. D., Kirkby, Susan M., and Ryan, D. M. (1968). In Laboratory Appraisal of Cephalexin. Antimicrobial Agents and Chemotherapy, edited by Gladys L. Hobby, pp. 353-360.

\section{The July 1972 Issue}

\section{THE JULY 1972 ISSUE CONTAINS THE FOLLOWING PAPERS}

Obituary A. G. Signy, Editor, Journal of Clinical Pathology, 1944-1972

Congenital dyserythropoietic anaemia with erythroblastic multinuclearity MALCOLM BRIGHT, JEREMY COBB, BYRON EVANS, AND T. E. PARRY

The influence of spleen size on the distribution of red cells and plasma P. J. TOGHILL AND SHEILA GREEN

Effect of feeding fat on fibrinolysis, stypven time, and platelet aggregation in elderly Africans J. C. FERGUSON, N. MACKAY, AND G. P. MCNICOL

Exfoliative cytology of diffuse mesothelioma $\mathrm{G}$. HEFIN ROBERTS AND G. M. CAMPBELL

Immunoelectroosmophoresis in the diagnosis of meningococcal infections BARBARA M. TOBIN AND D. M. JONES

In-use testing of disinfectants in hospitals JEAN PRINCE AND G. A. J. AYLIFFE

Serum $\alpha$-macroglobulins in renal disease and preeclampsia C. H. W. HORNE, J. D. BRIGGS, P. W. HOWIE, AND A. C. KENNEDY
Data processing in haematology M. G. NELSON AND E. ELDER

Red cell size as measured by the Coulter model $\mathbf{S}$ TAKASHI OKUNO

Some observations and improvements on SMA 6/60 determinations of creatinine MADELEINE CLOSEMOLL AND J. G. LINES

Present day practice

Immunoglobulin and intrinsic factor antibody in the sera of patients with pernicious anaemia HINGYAN SHUM, ARTHUR M. STREETER, AND BARRY J. O'NEILL

\section{Technical methods}

Simultaneous staining of phospholipids, basic proteins, and glycogen on the same slide B. PRESENTEY AND K. PERK

Book reviews

Supplement: Problems Related to FibrinolysisTheoretical and Clinical

Copies are still available and may be obtained from the PUBLISHING MANAGER, BRITISH MEDICAL ASSOCIATION, TAVISTOCK SQUARE, LONDON, WC1H 9JR, price £1.05. 